\title{
Combining experiential and social learning approaches for crop disease management in a smallholder context: a complex socio-ecological problem
}

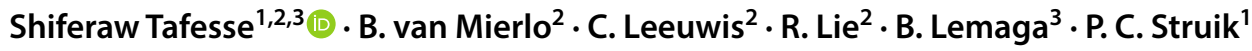

Received: 14 January 2020 / Accepted: 21 July 2020 / Published online: 5 August 2020

(c) The Author(s) 2020

\begin{abstract}
Effective management of crop diseases is a key precondition for sustainable crop production and to improve food security globally. However, learning approaches that improve smallholder farmers' knowledge, perceptions, and practices to deal with crop diseases by fostering social and technical innovations are seldom studied. A study was conducted to examine: (1) how a combination of experiential and social learning approaches influences potato farmers' knowledge, perceptions, and practices in bacterial wilt and its management in Ethiopia and (2) the implications of combining the two approaches for complex crop disease management in smallholder context. Data were derived from face-to-face in-depth interviews, reflective workshops, and participant observations. The findings showed that farmers' knowledge and perceptions about disease incidence, the pathogen that causes the disease, its spreading mechanisms, host plants, and disease diagnosis were changed. Farmers' practices in management of the disease were also improved. Learning about the cause of the disease stimulated the identification of locally relevant spreading mechanisms and the feasibility of a range of recommended disease management methods. Moreover, farmers recognized their interdependency, role, and responsibility to cooperate to reduce the disease pressure in their community. We conclude that learning interventions aiming to improve smallholder farmers' knowledge, perceptions, and practices to deal with complex crop diseases need to combine experiential and social learning approaches and consider farmers' local knowledge.
\end{abstract}

Keywords Experiential learning $\cdot$ Social learning $\cdot$ Bacterial wilt $\cdot$ Disease control $\cdot$ Complex problem $\cdot$ Collective action $\cdot$ Ethiopia

\section{Introduction}

Crop diseases are major biotic threats to global food security, exacerbating food supply deficit by reducing the quality and yield of crop production (Savary et al. 2019; Strange and Scott 2005). Effective management of crop diseases has, therefore, significant implications for sustainable crop

Shiferaw Tafesse

shiferawtafesse.gobena@wur.nl; shiferaw.tafesse@gmail.com

1 Centre for Crop Systems Analysis, Wageningen University, PO Box 430, 6700 AK Wageningen, The Netherlands

2 Knowledge, Technology and Innovation Group, Wageningen University, PO Box 8130, 6700 EW Wageningen, The Netherlands

3 CGIAR Research Program on Roots, Tubers and Bananas (RTB), International Potato Center (CIP), PO Box ILRI clo CIP 5689, Addis Ababa, Ethiopia production and food security. If the yield loss caused by various crop diseases could be minimized, the availability of food would be improved for millions of people who currently lack sufficient food. Notably, in sub-Saharan African countries where yield loss due to crop diseases is much higher than in the rest of the world (Savary et al. 2019; Tadele 2017), smallholder farmers would benefit most from effective disease management. Crop disease management in smallholder farmers' context has received considerable attention over the last decades, but yield loss due to the impact of various types of crop diseases has continued to hinder crop production (Roopa and Gadag 2019).

Potato (Solanum tuberosum L.) is one of the most important food crops produced worldwide (Devaux et al. 2014; FAO 2008). This crop is affected by various types of infectious diseases caused by bacterial, fungal, oomycete, and viral pathogens (Stevenson et al. 2001). Bacterial wilt, prevalent in potato production systems in many parts of the 
world, is the most difficult potato disease to manage (Elphinstone et al. 2005, p. 9; Yuliar et al. 2015, p. 2). Its management is difficult mainly due to the nature of the pathogen responsible for the disease, Ralstonia solanacearum. This pathogen has diverse spreading mechanisms and infects more than 200 plant species, including many food crops such as tomato, eggplant, and pepper (Elphinstone et al. 2005; Genin 2010; Hayward 1991). Since there is no single effective control method for bacterial wilt, several studies have shown the importance of integrating different management methods (Allen et al. 2005; Elphinstone 2005; Lemaga et al. 2005; Yuliar et al. 2015). The integration of farm sanitation and cultural practices such as crop rotation, roguing infected plants, use of disease-free seeds, and decontamination of farming tools have been recommended as plausible approaches to control the disease in smallholder farmers' context (Elphinstone and Aley 1993; Lemaga et al. 2001, 2005; Yuliar et al. 2015).

In Ethiopia, potato production has been widely promoted as a strategic crop for food security. Currently, more than 3.7 million smallholder farmers grow potato for food and income generation. The country has faced a dramatic expansion of potato bacterial wilt in the past few years (CIP 2016; Gorfu et al. 2013). Following the expansion of potato production in the country, the disease has spread aggressively, posing a threat to the country's ware and seed potato production systems (Abdurahman et al. 2017; CIP 2016; Gorfu et al. 2013). It is currently causing a significant reduction in potato yield in many districts, affecting the income and food security of millions of potato farmers (Abdurahman et al. 2017; CIP 2016; Gorfu et al. 2013). Despite the detrimental effect of the disease in the country, so far, only limited research and extension efforts have been made to tackle it.

Limited knowledge of farmers and extension workers on various aspects of the disease and its management methods, coupled with a weak extension system, have been identified as major constraints to effective disease management (CIP 2016; Gorfu et al. 2013; Tafesse et al. 2018). Most of the farmers recognize only the importance of roguing infected potato plants as an effective management method without understanding the diverse technical and social dimensions of the disease and its management methods. In this regard, many farmers rogue an infected plant and throw it away at the farm side, which appears to facilitate the spreading of the disease instead of controlling it (Tafesse et al. 2018).

Many studies have underscored the importance of a community-based approach to control potato bacterial wilt effectively. Since the disease is contagious and a collective risk problem, a concerted effort among farmers is required (Lemaga et al. 2005; Tadesse et al. 2019; Van de Fliert 1993; Van der Plank 2013; Yuliar et al. 2015). To this end, the farmers need to recognize their interdependency which is currently not the case (Damtew et al. 2018). They also need to have a good understanding of the causal agent, symptoms, spreading mechanisms, and management methods of the disease (Tafesse et al. 2018). This may not be realized without meaningful learning. In the Ethiopian potato production system, previous efforts toward enhancing farmers' capacity have been primarily concentrated on promoting technical solutions through training targeting seed potato farmers. The key actors in the system tend to overlook the social dimensions of the problem (CIP 2016; Damtew et al. 2018). Ethiopian agricultural extension is hierarchical and follows primarily linear approaches for knowledge and technology transfer (Damtew et al. 2018; Spielman et al. 2011, p. 204).

Such conventional approaches oversimplify the complex and nonlinear learning processes and have been criticized by several scholars (Leeuwis 2004; van Mierlo et al. 2010; Spielman et al. 2011). Scholars of communication for innovation, knowledge systems, socio-ecological systems, and innovation systems emphasize the importance of learning collectively instead (Colding and Barthel 2019; Leeuwis 2004; Pahl-Wostl 2006; van Mierlo et al. 2010, p. 324). Learning linked to innovation is regarded as an interactive process (van Mierlo et al. 2010). Several learning approaches for searching solutions for complex agricultural problems have been proposed and discussed in the literature (Leeuwis and Pyburn 2002; Röling and Wagemakers 1998; van Mierlo and Beers 2018). In this literature, an innovation systems approach is suggested for sustainable crop protection in which farmers are considered as partners in the innovation process, instead of adopters of knowledge and technologies. In line with this view, learning interventions to foster social and technical innovations that fit the local context need to acknowledge and integrate farmers' local knowledge to be effective and sustainable.

Experiential learning is a prominent learning approach that has been widely applied in integrated management of crop pests and natural resources (Percy 2005; Pincus et al. 2018, p. 434). Using experiential learning as an underpinning theoretical perspective, the farmer field school (FFS) approach has been implemented in many developing countries. It has been shown that this approach has positive impacts on crop pest management, agricultural productivity, and income of smallholder farmers (Davis et al. 2012; Ortiz et al. 2004, 2019; Palis 2006). But since experiential learning largely focuses on learning through concrete experience when a learner interacts with a phenomenon or the environment, it is usually criticized for neglecting the social processes required to solve collective action problems (Fenwick 2000; Michelson 1999; Roberts 2006; Seaman 2008).

As crop disease management has complex social and ecological dimensions, experiential learning of individual farmers alone cannot be sufficient to learn about all aspects of the disease and innovations to address it (Leeuwis 2004). Learning among groups of interdependent 
farmers is also needed for effective coordination of collective action (Leeuwis 2004, p. 196). Hence, experiential learning needs to be combined with learning techniques that foster interactions to develop shared meanings that serve as a basis for collective action.

For collective management of complex socio-ecological problems, the concept of social learning has become increasingly important (Keen et al. 2005; Leeuwis 2004; Leeuwis et al. 2002; van Mierlo and Beers 2018). In social learning, interdependent actors interact, learn together, and reach consensus to deal with joint complex problems collectively. Besides, social learning enables reflection of diverse views, instigates new relationships and fosters the development of trust among different actors (Keen et al. 2005; Leeuwis et al. 2002; Reed et al. 2010).

Thus, a learning approach that combines elements of experiential and social learning may foster effective control of the disease. This study was therefore conducted with the objective of investigating how the integration of experiential and social learning approaches could stimulate learning to control complex crop diseases such as bacterial wilt in smallholder farmers' context. To achieve the overall objective, two related research questions were formulated:

1. How does a learning intervention with a combination of experiential and social learning approaches influence farmers' knowledge, perception, and practices in potato bacterial wilt management?

2. What are the implications of combining experiential and social learning approaches for management of complex crop diseases in smallholder context?

The structure of the remaining parts of the article proceeds as follows: Sect. 2 describes the concepts of experiential and social learning and explicates how changes in reasons for action are used as evidence of learning. This leads to the conceptual framework of this study. Section 3 describes research methodology, including study setting, learning intervention, data collection, and analysis. Sections 4 and 5 present the results of the study and discussions of the findings, respectively. Finally, the conclusion is provided in Sect. 6.

\section{Conceptual framework}

This section discusses the theoretical foundations of the study and describes how the concepts of experiential and social learning are combined and operationalized for designing a learning intervention on the management of potato bacterial wilt. Further, this section explains the concept of learning and changes in reasons for action as areas of learning.

\subsection{Experiential learning}

Experiential learning is commonly defined as a process in which learning is embedded in a learner's experience (Kolb 1984, p. 38). Several scholars have described the relationship between experience and learning. For instance, according to Kolb (1984), the experience is transformed to create knowledge through a learning process. A similar perspective is also held by Boud et al. (1985), who explicates experience as a source of learning. In experiential learning, a learner is actively involved in making a choice and applies the knowledge gained from experience (Beard and Wilson 2006; Kolb 2015). In the literature, experiential learning is broadly characterized in two ways: the process of experiential learning and how the process can be supported for experiential learning to happen (Beard and Wilson 2006; Kolb 2015).

Kolb (2015, p. 51) describes the experiential learning process as a learning cycle with four phases that represent the order in which learning takes place: (1) concrete experience, (2) reflective observation, (3) abstract conceptualization, and (4) active experimentation. Concrete experience is considered as a starting point for experiential learning to take place. Various methods have been described in the literature to support each learning stage of the experiential learning cycle, including direct experience, field trips, demonstrations, dramatic participation (role plays), visual symbols, pictures, recordings, information and communication technologies, and exhibits (Kolb 2015; Lie and Witteveen 2018; Roberts 2006). Leeuwis (2004) expands how extension workers can support farmers to be able to go through the learning cycle. Among others, concrete experiences can be supported by visualizing a phenomenon, while reflective observation can be supported by facilitating discussions. Likewise, abstract conceptualization and experimentation can be supported by crafting a pattern and organizing an experiment, respectively (Leeuwis 2004).

In rural settings, many scholars consider experiential learning as a pertinent feature of learning approaches to enhance farmers' capacity to effectively deal with various complex farming problems (Leeuwis 2004; Percy 2005; Pincus et al. 2018; Roberts 2006). Consequently, experiential learning has been widely applied as a theoretical basis for extension interventions in the context of adult learning (Leeuwis 2004; Roberts 2006). For instance, the theoretical perspective underlies farmer field school (FFS), an approach that focuses on discovery learning to help farmers become better decision-makers (Ortiz et al. 2019; Suzanne Nederlof and Odonkor 2006). Over the last decades, FFS has been widely promoted in rural settings in many developing countries (Ortiz et al. 2004; Palis 2006). Despite this extensive application, experiential learning has also been criticized. It is a model that explains how individuals learn and it does not consider social processes (Roberts 2006; Seaman 2008, 
p. 4), which are critical to deal with complex problems that require collective agreement among interdependent actors for concerted action (Leeuwis and Pyburn 2002; Pahl-Wostl 2006).

\subsection{Social learning}

Social learning is a widespread concept in the literature on the management of natural resources (Noguera-Mendez et al. 2016; Rodela 2013; van Mierlo and Beers 2018). It has predominantly been described in multi-stakeholder processes for the development of joint actions. The literature shows that social learning occurs when interdependent actors come together and interact in facilitated meetings or workshops (Beers et al. 2016; Pahl-Wostl 2006; Reed et al. 2010). Hence, mutual dependence for effective natural resource management is a key precondition for social learning to take place. The interaction among diverse actors can be regarded as the input of social learning (Beers et al. 2016). Furthermore, similar to the case of experiential learning, social learning benefits from deliberate facilitation. During the facilitation process, learning can be stimulated through interactive approaches like role plays (Leeuwis and Pyburn 2002; Paolisso et al. 2019; Pahl-Wostl et al. 2007).

A collective agreement among the actors as a way to go or as a solution for complex socio-ecological problems is considered an outcome of social learning. In this regard, scholars distinguish two types of social learning outcomes: cognitive and relational. The cognitive outcome refers to new knowledge and solutions for the common problem. The relational outcome includes the development of trust and recognition of the interdependency among the actors (Beers et al. 2016; Keen et al. 2005). The learning outcomes serve as a basis for collective action (Keen et al. 2005; Leeuwis and Pyburn 2002). Collective action among interdependent actors is therefore imperative since individuals cannot have all the answers to deal with complex problems (Pahl-Wostl et al. 2007). Several studies show that social learning enables negotiations and fosters development of new institutions required to guide the relationships among the actors with different perspectives and their roles (Colding and Barthel 2019; Paolisso et al. 2019; Pahl-Wostl 2006; Pahl-Wostl et al. 2008). This perspective is also relevant to the management of potato bacterial wilt; an effort of an individual farmer alone cannot be effective unless other farmers in the same community make concerted efforts.

\subsection{A framework for learning interventions and learning evidence}

From a learning process point of view, learning can well be studied from both an experiential and a social learning point of view, as explained above. Evidence for learning tends to be only considered as a change in an individual's or group's knowledge and understanding in relation to the social, economic, biophysical, and technical aspects. This narrow perspective focuses only on the cognitive elements of learning (Leeuwis 2004; van Mierlo et al. 2010). According to Leeuwis (2004), learning includes diverse social drivers and the relationships between understanding and action. Hence, what people do and do not do is influenced not only by their knowledge (perception of reality) and their capacities, but by their perceptions regarding social pressure, aspirations, trust, and roles and responsibilities as well. Evidence of learning, therefore, can be broadly defined as a change in any of these perceptions (Leeuwis 2004, p. 66).

Based on the above perspective, we developed a conceptual framework for this study as portrayed in Fig. 1. Experiential learning is mainly seen to occur when farmers' knowledge about diverse technical aspects of bacterial wilt is changed, when farmers experiment disease management methods, and when they are able to identify local conditions that contribute to disease spread, and the feasibility of different management methods of the disease in their context. Social learning may also contribute to these learning outcomes (indicated by the broken line in Fig. 1). On the other hand, social learning is mainly seen to take place when farmers recognize their interdependency, when collective goals or solutions are defined, and when the relationships among seed and ware potato farmers are changed as well as their perceptions on social pressure, trust in their social environment, and their roles and responsibilities. Experiential learning can also contribute to social learning outcomes (indicated by the broken line in Fig. 1). Changes in reasons for action are taken as evidences of experiential and social learning processes. They are essential conditions for effective management of potato bacterial wilt.

\section{Research methodology}

This section describes the study context and the methodology employed for data collection and analysis.

\subsection{Description of study settings}

Two villages, Agota and Wanjala, with different socio-ecological conditions, were selected from Wolmera and Doyogena districts in Ethiopia, respectively. Wanjala village is about $260 \mathrm{~km}$ south from Addis Ababa, whereas Agota is located at $50 \mathrm{~km}$ in the west of the city (Fig. 2). The two districts are located about $300 \mathrm{~km}$ apart. They are among the major potato growing districts in the central highlands of Ethiopia, where the problem of bacterial wilt is prevalent. The two districts were selected because of (1) high prevalence of bacterial wilt in the areas, (2) limited farmers' 


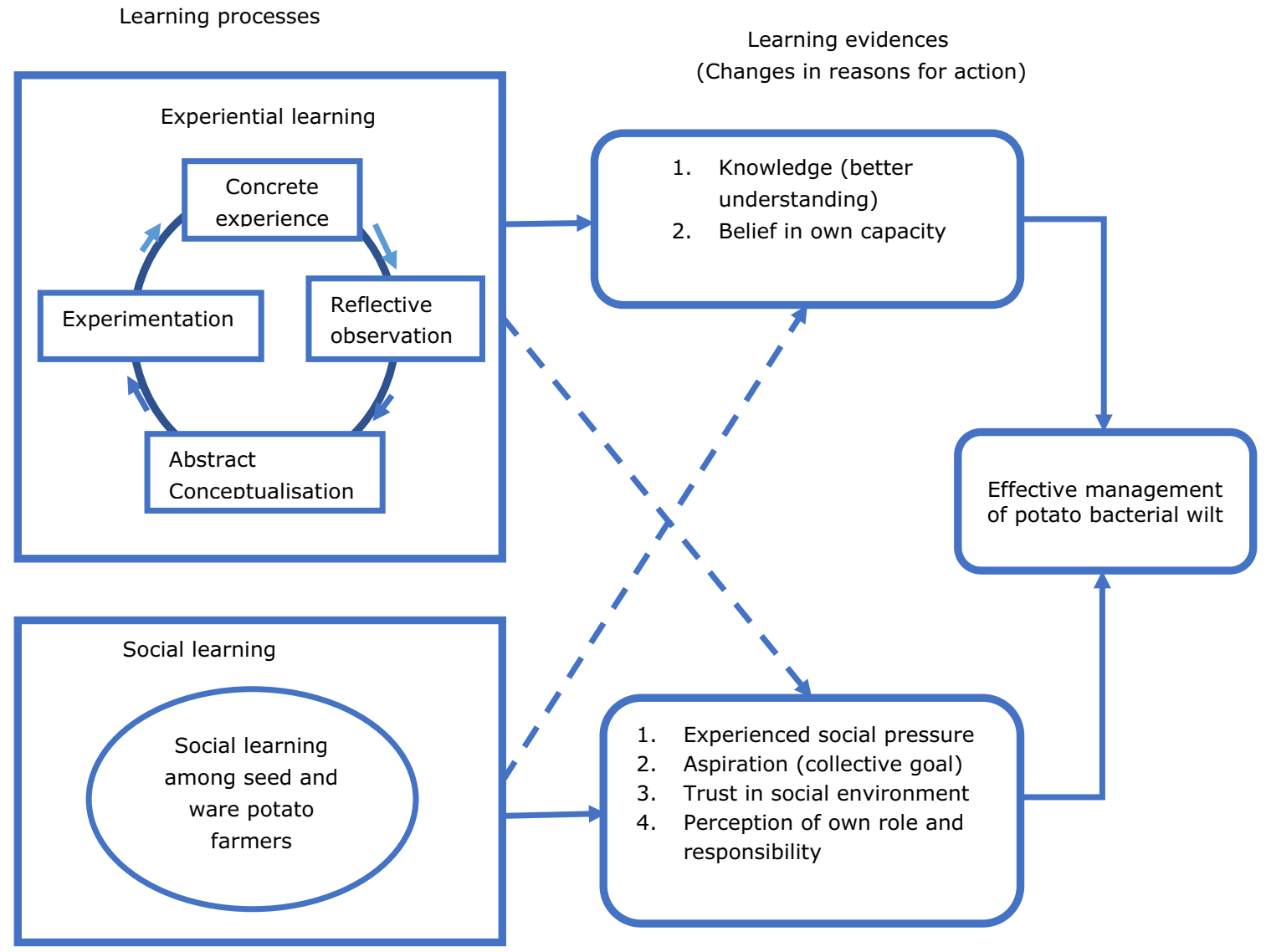

Fig. 1 Conceptual framework developed for this study

knowledge of bacterial wilt and its management methods, and (3) the presence of seed and ware potato growers. Also, the two districts provide contrasting disease management challenges and opportunities due to their differences in farming systems and socio-ecological conditions. Wolmera district has a cereal-based farming system, while Doyogena district has an enset-based (Ensete ventricosum) farming system. Moreover, farmers in Wolmera district own relatively larger potato fields than the farmers in Doyogena district.

In Ethiopia, the second-most populous African country, agriculture plays a dominant role in the country's economy. More than $95 \%$ of the agricultural land is owned by smallholder farmers (Gebre-Selassie and Bekele 2012). Crop diseases cause considerable pressure on food security efforts, like in many other developing countries. Thus, investigating how farmers learn for the management of crop diseases in Ethiopia gives an exciting insight into how to enhance smallholder farmers' capacity to deal with complex crop diseases in the developing world.

The study focuses on both seed and ware potato producers because both should be involved in concerted efforts for disease management. The farmers in Wanjala village are quality declared seed (QDS) producers and ware potato producers, whereas the farmers in Agota village are regular seed producers and ware potato producers. Quality declared seed producers are members of a registered cooperative and conform to more strict seed quality standards. Regular seed producers are also members of a registered seed cooperative, but seed quality standards are less strict. In relation to bacterial wilt infection, QDS producers need to meet a zerotolerance level, whereas it is usually acceptable for regular seed producers as long as they remove infected plants from potato fields. In both villages, the farmers were organized to involve in a community-based approach for the learning intervention. Overall, 36 (29 males, 7 females) and 25 (21 males, 4 females) farmers participated in the learning intervention from Agota and Wanjala villages, respectively. The farmers of these villages grow potatoes both in Meher (main rainy season) and in Belg (short rainy season).

\subsection{Learning intervention}

This learning intervention was informed by the previous study that has examined farmers' knowledge and practices of potato bacterial wilt management in the study areas (Tafesse et al. 2018). Moreover, the learning intervention 
Fig. 2 Location map of the study villages in Ethiopia

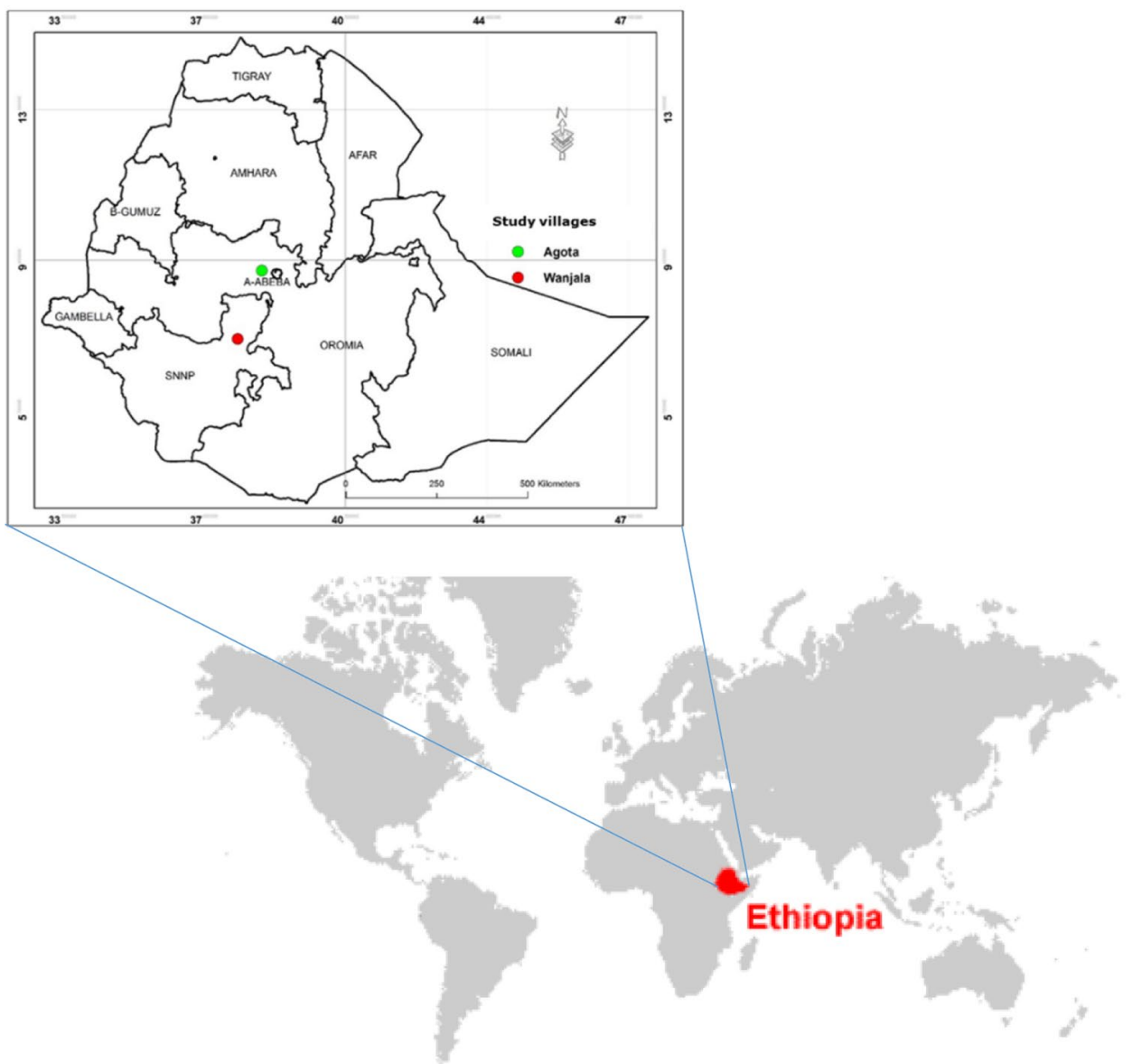

was designed to be interactive, acknowledge farmers' local knowledge and integrate it with the provided knowledge built on scientific insights. We designed and facilitated a learning intervention based on experiential and social learning theories. In both villages, a season-long communitybased learning intervention was implemented from May to November 2018, during the main potato growing season (Meher). The farmers who participated in the learning intervention were selected voluntarily in consultation with the respective district offices of agriculture and extension workers. The learning intervention was conducted in both villages using a manual prepared to facilitate the learning process. We developed the content of the manual based on the gaps identified by the previous study and the literature on potato bacterial wilt management. The major learning sessions include various aspects of potato bacterial wilt disease dynamics and its management methods through concerted efforts in a community-based approach, as indicated in Fig. 3.

The learning sessions were structured to address all aspects of the disease dynamics and what it takes to manage the disease in the farmers' local context effectively. In line with experiential learning theory, to stimulate this type of learning, there were many hands-on activities for farmers to gain new experiences and reflect on them in the light of their actions and results. Similarly, to enable social learning, reflective meetings were facilitated in which participant farmers performed role plays and interacted with each other to recognize their interdependency and the importance of collective action to manage the disease.

Nine learning sessions were conducted; each of them lasted between 2 and 4 h. Furthermore, there was a demonstration field (about $0.5 \mathrm{ha}$ ) owned by the participating farmers where they interacted and jointly implemented various types of bacterial wilt management methods. The group learning sessions also included theoretical discussions supported by color pictures and videos, practical field works, dynamic sessions, and role plays. The participating farmers performed and interacted to reinforce the topics of learnings. Furthermore, a reflective workshop was conducted to enable the farmers to reflect on what and how they learned various aspects of the disease and its management methods, and the way forward to manage the disease. Based on what they learned, the farmers gave their perspectives on which bacterial wilt management measures could (not) be feasible in their local context. 
Fig. 3 Learning topics introduced in the community-based learning intervention

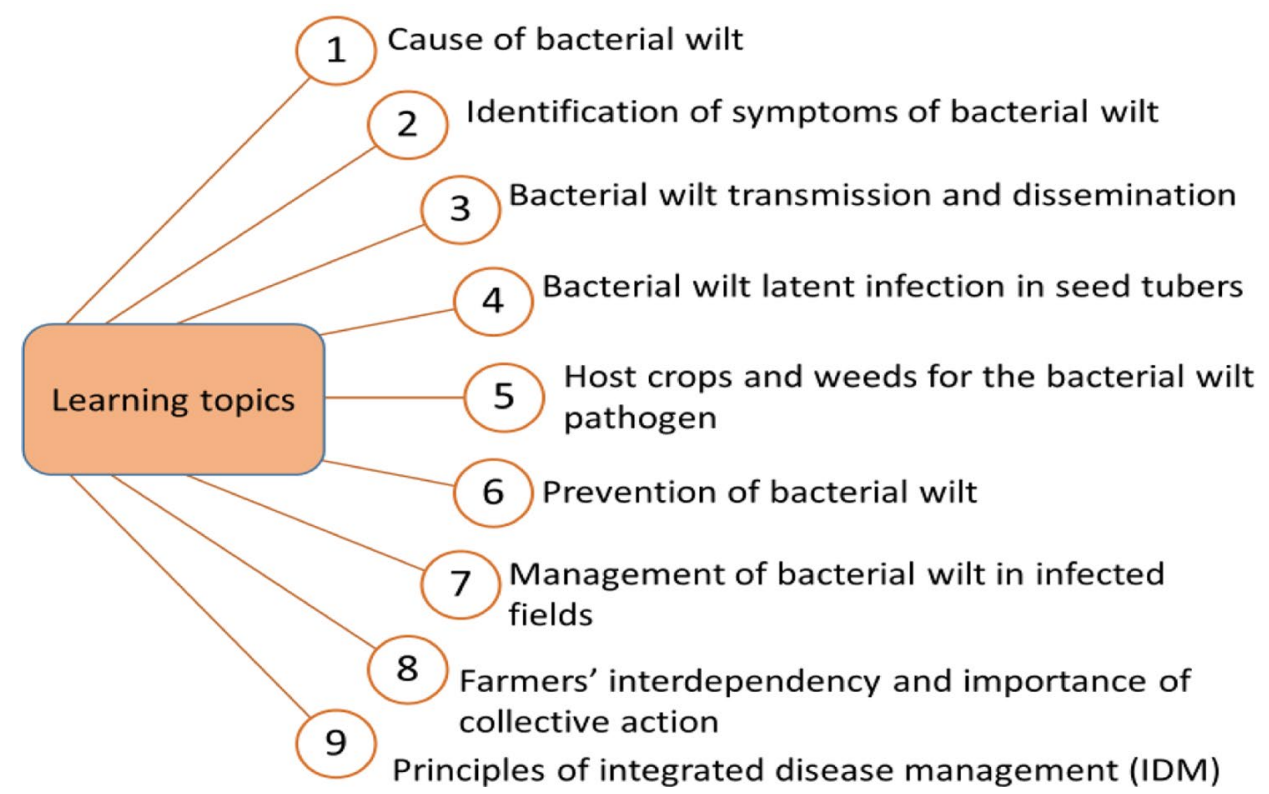

\subsection{Data collection}

Multiple methods of data collection were used to capture a complete view of farmers' learning to manage bacterial wilt (Table 1). During the learning sessions, participant observation was carried out by observing the farmers engaging in discussions and interactions between seed and ware potato farmers as well as by asking questions and participating in practical learning activities. Furthermore, farmers' potato fields and farmers' actions with respect to disease management methods were observed. The discussions during learning sessions were transcribed, coded, and analyzed. Quotes were also included around each evidence of learning.

Post-intervention in-depth interviews of farmers were used to provide qualitative data from the farmers who participated in the learning intervention. All participating farmers gave verbal consent for the interviews. The interviews were used to capture how and what they learned about various aspects of the disease and its management.

At the end of the growing season, reflective workshops were organized to reflect on what and how the farmers learned concerning bacterial wilt disease dynamics, disease

Table 1 Description of the research design

\begin{tabular}{|c|c|c|c|}
\hline Data collection methods & $\begin{array}{l}\text { Number of farmers } \\
\text { (males and females) }\end{array}$ & Village & Issues addressed based on the learning approaches \\
\hline Post-intervention interviews & $\begin{array}{l}36(29 \mathrm{M}, 7 \mathrm{~F}) \\
25(21 \mathrm{M}, 4 \mathrm{~F})\end{array}$ & $\begin{array}{l}\text { Agota } \\
\text { Wanjala }\end{array}$ & $\begin{array}{l}\text { Bacterial wilt dynamics (cause, spreading mechanisms, symptoms, } \\
\text { latent infection, host plants) } \\
\text { Disease management methods } \\
\text { How and what did the farmers learn } \\
\text { Importance of collective action } \\
\text { Change in perceptions about social pressure, trust in social environ- } \\
\text { ment, and their roles and responsibility }\end{array}$ \\
\hline Reflective workshops & $\begin{array}{l}30(24 \mathrm{M}, 6 \mathrm{~F}) \\
18(15 \mathrm{M}, 3 \mathrm{~F})\end{array}$ & $\begin{array}{l}\text { Agota } \\
\text { Wanjala }\end{array}$ & $\begin{array}{l}\text { Feasibility of a range of disease management methods } \\
\text { Conditions that affect the feasibility of recommended disease man- } \\
\text { agement methods } \\
\text { Importance of collective action } \\
\text { Change in perceptions about social pressure, trust in social environ- } \\
\text { ment, and their roles and responsibility }\end{array}$ \\
\hline $\begin{array}{l}\text { Participant observation discussions dur- } \\
\text { ing learning sessions }\end{array}$ & $\begin{array}{l}36(29 \mathrm{M}, 7 \mathrm{~F}) \\
25(21 \mathrm{M}, 4 \mathrm{~F})\end{array}$ & $\begin{array}{l}\text { Agota } \\
\text { Wanjala }\end{array}$ & $\begin{array}{l}\text { Identification of local conditions that contribute to spreading of the } \\
\text { disease } \\
\text { Reflection of farmers on different topics of learning }\end{array}$ \\
\hline Participant observation in both villages & & & $\begin{array}{l}\text { Implementation of disease management methods } \\
\text { Interactions among farmers during learning sessions, hands-on } \\
\text { activities, and reflective workshop }\end{array}$ \\
\hline
\end{tabular}


management methods, recognition of interdependencies, trust in the social environment, collective aspiration, and change in perceptions about their roles and responsibilities. The reflective workshops provided an important platform for discussions and reflections on the learning processes and evidence of learning. The reflective workshops were facilitated to collect data using well-prepared questions by guiding the discussions around each thematic area.

\subsection{Data analysis}

The collected data were analyzed with a qualitative approach. They were coded and grouped into different themes, and the learning processes as portrayed in the conceptual framework introduced in Sect. 2.3. Transcripts from the in-depth interviews and notes from the discussions during learning sessions and reflective workshops were analyzed manually to obtain farmers' reasons for action about potato bacterial wilt and its management in their context. Further, notes from field observations were used to understand farmers' reasons for action in relation to the implementation of various methods of bacterial wilt management.

\section{Results}

In this section, the extent to which experiential learning and social learning approaches influenced farmers' farmers' knowledge, perception and practices in potato bacterial wilt management is reported.

\subsection{Change in farmers' knowledge on potato bacterial wilt disease}

\subsubsection{Causal agent of bacterial wilt and its spreading mechanisms}

During reflective meetings and interviews, the farmers articulated a good understanding of the pathogen that causes bacterial wilt and its nature. Farmers described that they acquired new knowledge about the causative agent of the disease. They explained that they were surprised to learn that the disease is caused by a pathogen, a living thing, which grows and multiplies. In addition, before the learning intervention, they thought that this disease was caused by improper post-harvest handling of seed potato and due to high moisture during harvesting time. The statement of a seed potato farmer from Agota village is illustrative of many farmers. He said:

I am surprised to learn that this disease (bacterial wilt) is a contagious disease caused by an organism that lives in soil, water and seed potato.
Concerning the spreading mechanisms of bacterial wilt, farmers reported acquiring new knowledge of different spreading mechanisms. Many farmers explained that infected seed potatoes and contaminated farm tools are major spreading mechanisms. The farmers explained that they did not know whether their neighbor's potato fields infected by bacterial wilt could be a source of infection to their potato fields. They underlined the importance of keeping an eye on what is happening on their neighbors' potato fields.

On top of the spreading mechanisms that were presented during the learning sessions, the farmers indicated some additional mechanisms that are relevant in their local context. Farmers in Agota village explained that ravens usually eat potato tubers at the germination stage and move from one potato field to the other, flying and landing on many potato fields. Hence, they asked whether ravens may spread bacterial wilt through their beak and nails. Similarly, farmers in Wanjala village stated that in their village, most farmers rely on one or two farmers who own knapsack sprayers to spray their potato fields. The farmers wondered whether this practice could spread bacterial wilt because these farmers move from one potato field to the other without cleaning their shoes.

Some farmers also mentioned that they now understood why the extension workers were telling them to remove a wilted potato plant from their potato fields, which they did not understand before, that is, to avoid transmission of the disease to other plants. Moreover, the farmers mentioned that before the learning sessions they were expecting that some wilted potato plants would get healed. They had learned that keeping a wilted potato plant in the field would make the disease spread to other potato plants. The farmers also reported that bacterial wilt has no treatment once the plant is infected. A statement by a seed potato farmer from Wanjala village provides further illustrative evidence of the new knowledge that the farmers acquired about the causes and transmission mechanisms of the disease. He described it as follows:

This disease (bacterial wilt) is like AIDS. Because as AIDS transmits through sharp materials, bacterial wilt transmits through farm tools and it kills potato plants.

\subsubsection{Latent (symptomless) infection of bacterial wilt}

The farmers noted that they were amazed to learn the symptomless infection of the disease. Various comments by the farmers illustrate that they learned the symptomless infection of the disease. For example, during the fieldwork on the demonstration plot, a farmer from Agota village said "This potato is very healthy," pointing to a very vigorous potato plant. But other farmers reacted to this farmer's statement by 
uttering we cannot be sure whether it is healthy or not, the disease may not show symptoms. Maybe it is now sleeping and will wake up in the weeks to come.

On the other hand, during the reflective workshop, the farmers stated that understanding the possibility of symptomless infection of the disease would help them become cautious when they buy seed potatoes from the local market or from neighbor farmers. They remembered well the analogy, a sleeping man and potato with latent infection, used to explain the nature of the disease during the learning intervention. Further, many farmers expressed their concern about the difficulty to identify latently infected seed potato tubers when they buy seed.

\subsubsection{Host plants of bacterial wilt}

The farmers were able to identify different host plants that could be affected by the pathogen that causes bacterial wilt. When asked to explain plants that could serve as hosts for the disease in their village, other than potato, the farmers in Agota village mentioned tomato and tobacco, as farmers in this area grow these crops. Similarly, the farmers in Wanjala village mentioned tomato and pepper as host plants that could be affected by the disease. Further, the farmers were able to describe that potato should not be rotated with these host plants. Farmers from Agota village mentioned that potato should be rotated with cereals like wheat, maize, barley, and teff. Similarly, the farmers in Wanjala village were able to note appropriate crop rotation patterns excluding host plants.

\subsection{Farmers' belief in their own capacity to manage bacterial wilt}

\subsubsection{Implementation of disease management methods}

Farmers asserted that they were equipped to protect their potato from the disease and sustain its production. They reported that, as a result of the learning intervention, they felt confident and capable of managing bacterial wilt using their new knowledge of the disease and its management methods. They specifically stated that the practical learning activities on the demonstration plot helped them to sufficiently learn how to diagnose the disease and control it. During the interviews, the farmers could describe a range of bacterial wilt management methods and their feasibility in their local context.

The farmers implemented farm hygiene and sanitation measures that would help them manage the disease. During the reflective workshops, the farmers asserted that they kept the hygiene of their potato fields. For instance, one farmer from Agota village explained that he put a fence around his potato field to avoid interference from humans and cattle, to avoid the disease. Besides, many farmers constructed ditches around their potato fields to divert surface runoff from their potato fields. Further, the farmers reported that they decontaminated farm tools using fire and hot water.

The farmers also reported that they cleaned their shoes before entering their potato fields. But they stated that they used water alone to clean their shoes. They also mentioned that monitoring committee members who used to visit each farmer's field by walking on potato fields without considering the importance of cleaning their shoes started cleaning their shoes. During the interviews, a lot of farmers were smiling thinking about what they used to do due to the limited knowledge they had. Overall, as noted in the quotes below, farmers developed confidence by learning how to manage the disease. The following illustrative quote is what many farmers asserted during the interviews and the reflective workshops.

I did not know how to manage this disease aside from removing wilted plants from my potato field. But now, I have learned many disease management methods.

Furthermore, the farmers, particularly ware potato producers, reported that they learned the importance of crop rotation and using clean seed. However, they reported that due to the unavailability of quality seed potato, using clean seed was difficult. Concerning crop rotation, the farmers stated that they usually practise one or two seasons of crop rotation interval and they would try to increase the interval although land shortage would constrain this practice as highlighted below:

I have been practising crop rotation to improve soil fertility. I did not know that crop rotation could help us manage this disease but now, I have learned, and I will surely implement it starting from next season.

Further, the farmers modified their practice of roguing infected plants from their potato fields. They mentioned that they started roguing and properly disposing of the infected potato plants either by burying in a deep pit or by burning. But they described the difficulty of undertaking uprooting of the infected potato plants when they are too many. They said it is a very laborious activity to uproot and bury or burn infected potato plants regularly.

\subsubsection{Diagnosis of bacterial wilt incidence}

The interviews with farmers revealed that they developed practical skills to conduct proper disease diagnosis. During fieldworks on demonstration plot and their potato fields, the farmers were able to identify disease symptoms. They could diagnose the disease on potato leaves and tubers. However, many farmers explained the difficulty of making bacterial wilt disease diagnosis when their potato field is affected both 
by late blight and bacterial wilt at the same time. This is true because severe infection of late blight destroys the whole potato leaves and stems.

\subsubsection{Identification of local conditions that spread bacterial wilt}

Discussions held with farmers after the learning sessions and during the reflective workshops revealed that they could identify many local conditions that spread bacterial wilt in their village and beyond. The farmers mentioned the practice of seed potato exchange between seed potato farmers and ware producers as one of the conditions that may aggravate the spreading of the disease. Other local conditions that were identified by the farmers as contributing to the spread of the disease include the exchange of labor, sharing of farm tools, and free grazing of cattle on potato fields. The following illustrative statement given by the farmers shows how they demonstrated their enhanced capacity in recognizing local conditions that may spread the disease.

We usually work together through a labor exchange approach for planting, weeding and harvesting potatoes. In this case, all the farmers bring their farm tools to work on their neighbour's fields. We now recognize that this practice can contribute to the spreading of the disease and we need to clean the farm tools and our shoes.

Furthermore, seed potato farmers who have relatively big potato fields hire labor for weeding and harvesting, which can open a way for the disease to spread. Farmers described that this practice could spread bacterial wilt since hired laborers did not clean their shoes when they work for many farmers in different potato fields. The farmers expressed that it would be challenging to stop labor exchanging. But they asserted to try their best to make sure that farm tools are cleaned enough not to spread the disease. Likewise, concerning seed potato exchange, the farmers explained that stopping this practice would be very difficult. This was because most farmers strive to grow improved potato varieties that they usually buy or get from their neighbors. In this regard, the farmers suggested trying to buy seed potato from the agricultural research center or from farmers whom they know that their potato fields are not affected by the disease. Based on the discussions held with farmers and field observations, analysis of the routes of disease spreading among potato fields owned by different types of farmers in the study villages is indicated in Fig. 4.

\subsection{Identification of the feasibility of bacterial wilt management methods}

During the reflective meetings, the farmers demonstrated their learning by describing the feasibility of various recommended bacterial wilt management methods considering their context. They were asked to rank the feasibility of several methods as extremely difficult to implement, slightly difficult to implement, or easy to implement. They demonstrated their capacity by rating the feasibility of the recommended methods for management of the disease considering their local context as indicated in Table 2.

Farmers in both study villages rated disease management methods such as the use of disease-free seed potato and planting potato on disease-free fields as extremely difficult to implement. Using disease-free seed potato is not possible due to a lack of access to certified seed potato in the country. The wide prevalence of the disease in the study areas also made it very difficult to find a potato field free from the infestation of the disease by the farmers in their respective village. Similarly, eradicating host weeds and washing oxen hooves were rated by the farmers in both villages as extremely difficult to implement. The farmers mentioned that since there were many types of weeds in their potato fields, it was very difficult to eradicate them so

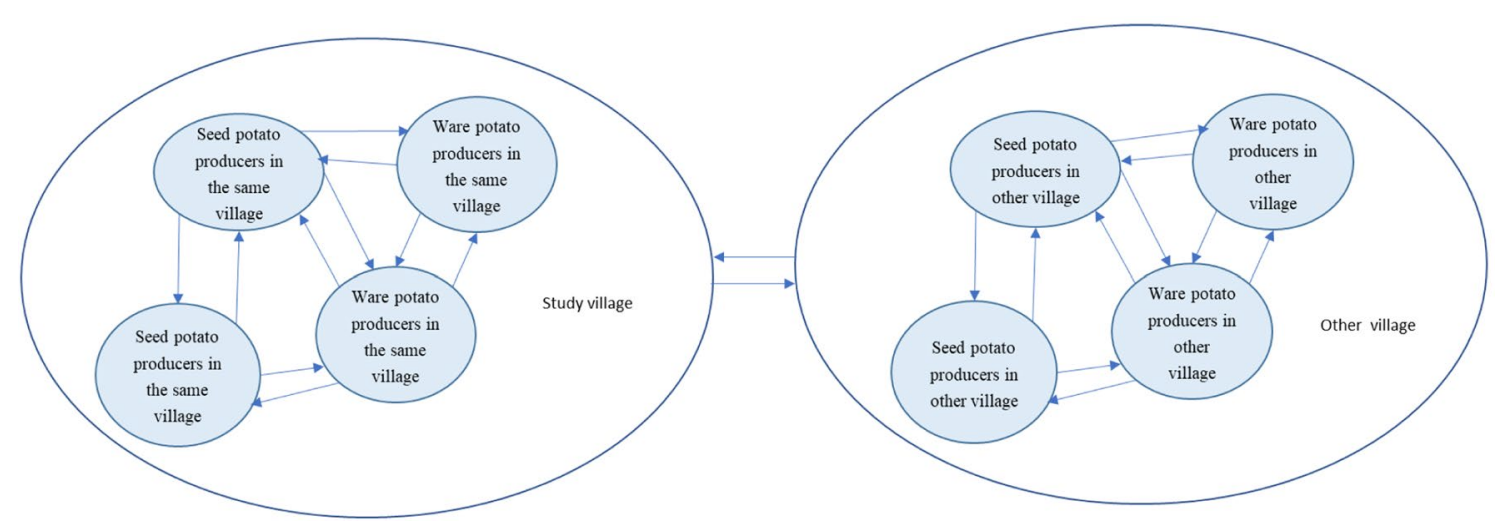

Fig. 4 Schematic representation of the possibility of the spreading of bacterial wilt of potato from seed producers to ware potato producers and vice versa in the study villages and beyond 
Table 2 Farmers' rating of the feasibility of potato bacterial wilt management methods in their local context

\begin{tabular}{lll}
\hline Recommended methods for management of potato bacterial wilt & $\begin{array}{l}\text { Agota village } \\
\text { (Wolmera district) }\end{array}$ & $\begin{array}{l}\text { Wanjala village } \\
\text { (Doyogena } \\
\text { district) }\end{array}$ \\
\hline Decontamination of farm tools & $*$ & $*$ \\
Washing oxen hooves & $* * *$ & $* * *$ \\
Planting potato on disease-free fields & $* * *$ & $* * *$ \\
Roguing and burning or burying infected potato plants & $* *$ & $*$ \\
Using disease-free seed potato & $* * *$ & $* * *$ \\
Preparing cutoff drains to divert surface runoff & $*$ & $*$ \\
Practising crop rotation with non-host plants & & $* * *$ \\
Three seasons & $* *$ & $*$ \\
Two seasons & $*$ & $*$ \\
One season & $*$ & $*$ \\
Cleaning shoes before entering potato fields & $*$ & $* * *$ \\
Eradicating host weeds & $* * *$ & $* *$ \\
Controlling free grazing of cattle on potato fields & $* * *$ & \\
\hline
\end{tabular}

***Extremely difficult to implement, **slightly difficult to implement, *easy to implement that the disease would not get spread in the process of weed management. Further, they mentioned that they did not know specific host weeds for the disease in their villages. Concerning washing oxen hooves, the farmers in both villages expressed their concern about its feasibility. They mentioned that some oxen could be aggressive and trying to wash their hooves is unsafe. Furthermore, farmers think that washing oxen hooves is quite labor intensive, and thus, it is nearly impossible and challenging to implement.

On the other hand, farmers in both villages rated bacterial wilt management methods such as decontamination of farm tools, preparing cutoff drains to divert surface runoff, and cleaning shoes before entering potato fields as easy to implement. They mentioned that implementing these practices was easy and they managed to implement all of them in their potato fields. Interestingly, farmers in Agota village rated roguing and safely disposing of infected potato plants as slightly difficult to implement. Their reason was that since there were many infected plants per field, it was not easy to uproot and burn or bury in deep pits. The farmers in Wanjala village rated this method of bacterial wilt management as easy to implement, indicating the relatively lesser disease severity in the area.

The farmers in Agota village rated controlling the free grazing of cattle on potato fields as an extremely difficult method to implement. This was because in this village free grazing of cattle is a common practice and it is not easy to change it just to manage potato bacterial wilt. Particularly during the dry season, cattle herds from different areas graze freely on crop fields due to a shortage of animal feed. Further, the cut-and-carry system (where the grass is cut and fed to livestock) is not common in this village and the farmers mentioned the difficulty of stopping this practice in the face of bacterial wilt prevalence. In Wanjala village, farmers rated the same practice as easy to implement. This is because the number of cattle per household in this village is small compared to that of Agota village. Also, cattle are usually kept in a confined area and free grazing of cattle on several crop fields is not common in Wanjala village.

Concerning crop rotation, the farmers in both villages rated up to two seasons of interval between potato and nonhost crops as easy to implement. But the farmers in Agota village felt that three seasons of crop rotation was slightly difficult to implement due to land shortage and land fragmentation. Due to the same reason, farmers in Wanjala village considered crop rotation of three seasons as extremely difficult to implement in their local context.

\subsection{Change in social pressure}

The farmers became vigilant about what is happening in their neighbors' potato fields. Recognizing their interdependency, both seed and ware potato farmers started putting pressure on each other to manage the disease in their community. Particularly, seed potato farmers reported putting pressure on ware potato farmers to properly implement disease management methods to prevent it from spreading further. Ware potato farmers also urged seed potato farmers to give more attention to the quality of seed instead of the quantity they sell. Interestingly, farmers responded more to the pressure from their fellow farmers than to the technical advice provided by agricultural researchers and extension workers. During the reflective workshop, many farmers stated the importance of monitoring each other's potato fields for disease occurrence. 
When asked the reason why they implemented different methods of bacterial wilt management, seed potato producers stated that they wanted to get their produce accepted by seed potato cooperatives to be sold at a higher price. Seed potato growers became more worried and serious about the disease. These farmers explained that there was also a strong push from other fellow farmers to implement disease management methods due to the prevalence of bacterial wilt and its ramifications on the seed potato market. This shows that seed potato farmers who produce seed potato in the same village began compelling each other to control the disease. They also indicated that ware potato producers do not want to seed potatoes with symptoms of disease infection.

\subsection{Change in aspiration (collective goal)}

During the reflective workshops, farmers stated the importance of collaboration between seed and ware potato farmers. They described the disease as a common challenge that all potato farmers need to collaborate to control it. Seed potato farmers had a relatively better experience of working together for seed potato production, disease management, and marketing. Hence, they were more proactive about potato bacterial wilt and its management than ware potato producers.

Before the learning intervention, ware potato farmers did not recognize the importance of collective action to control the disease. Seed potato farmers also repeatedly noted that they did not consider the importance of collaborating with ware potato farmers before the learning intervention. But, during interviews and reflective workshops, the farmers stated that they would not be successful in controlling the disease through individual efforts alone as their potato fields are usually bordered by other farmers' fields. Both seed and ware potato farmers expressed the importance of collective action and agreed to make a concerted action. They proposed to work together to deal with the disease by developing bylaws. Regretting about the spread of the disease, a seed potato farmer from the Wanjala village, who is illustrative of many farmers, said:

If we had learned about this disease before starting seed potato multiplication, we would not have let it spread in our area and our seed potato business would have continued successfully. Unknowingly, we have put ourselves in a serious problem, but now we started correcting our past mistakes.

Similarly, a seed potato farmer from Agota villages said the following, indicating the importance of collective action to manage the disease:

When research centre and office of agriculture give us some trainings on seed potato production and disease management, they do not include ware potato farmers with us. Now I have understood the importance of learning together to jointly fight this disease.

\subsection{Change in trust in social environment}

The study revealed that farmers changed their perception of the social environment. The interviews revealed that the farmers used to think that improved potato varieties supplied by seed potato cooperatives, the office of agriculture, and individual seed potato farmers were clean and free from different potato diseases. However, after they learned about the nature of bacterial wilt and considering the prevalence of the disease in their community, the farmers reported that they would no more trust the quality of seed potato supplied by these actors. The farmers stated that they needed more help from the research center to control this disease because the office of agriculture could not give them disease-free seed. Many farmers declared that they would put their trust in a seed potato from a research center. Some farmers even suggested stopping buying seed potatoes from the local market because of disease prevalence. Many farmers expressed their frustration in the poor quality of seed potato they bought from local markets. This is illustrated by the following quote:

Last year, I bought Gudene (improved potato variety) from a seed potato producer in our village. But it was severely affected by a disease and the yield was less than a local variety.

On the other hand, seed potato producers expressed their worries about the lack of market for their seed production. They perceived that their seed potato business would be in trouble given the prevalence of the disease. It was also observed that many seed producers started selling their seed produce as ware potato fearing unavailability of market. Many seed potato farmers hesitated to store seed potato in diffused light store (DLS) due to the lack of a reliable market. They preferred to sell to ware potato traders to avoid the risk of market unavailability. As the seed potato farmers used to get appreciable income from seed potato business, they recurrently expressed their frustration about the devastating nature of the disease during the reflective workshop. A seed potato farmer from Agota village said in this regard:

Lack of market for seed potato has already discouraged us. We sell our seed potato produce to ware potato traders at a lower price.

During the reflective workshop, the farmers in both study sites expressed their dissatisfaction with the unavailability of disease-free seed potatoes in their area. They were also shocked to learn that at some point their fate of growing potato could be ruined by the disease if it is left unmanaged. 
Besides, the farmers expressed their concern about the disease pressure and they developed a sense of urgency to deal with the disease.

\subsection{Change in perception of farmers' role and responsibility}

Both seed and ware potato farmers demonstrated a change in perceptions about their role and responsibility in ways that confirmed their learning. Ware potato farmers described that they used to blame seed potato farmers for the poor quality of seed they produced and sold. On the other hand, seed potato producers were claiming to implement disease management methods properly and produce quality seed potato. But during the learning intervention, both types of farmers admitted to unknowingly contribute to the spreading of the disease, in one way or another, and identified their roles and responsibilities they could have played. The farmers described playing the required role for effective management of the disease by properly implementing disease management measures in their potato fields. They also agreed to take responsibility to clean farm tools when they help each other through labor exchange, not to spread the disease to their neighbors' potato fields. Besides, the farmers agreed to take responsibility to tell their respective family members not to use a hoe without cleaning it, and not to enter potato fields without cleaning their shoes. For instance, a seed potato farmer said:

When my neighbor helped me in hilling of potato, I reminded him to clean his hoe and shoes before he started working.

\section{Discussion}

In this section, the results of the study on the influence of experiential and social learning approaches on farmers' knowledge, perceptions, and practices related to bacterial wilt management are discussed. We present effects of the experiential learning characteristics, then of the social learning characteristics, and finally the synergy between the two approaches.

\subsection{The influence of experiential learning on farmers' knowledge, perceptions, and practices in bacterial wilt and its management}

The study showed that experiential learning contributed to change in farmers' knowledge, perceptions, and practices of bacterial wilt disease dynamics and management. The farmers reported that hands-on activities on the demonstration plot motivated and enabled them to implement disease management methods in their potato fields. For example, they removed and buried or burned infected potato plants, cleaned their shoes before entering potato fields, decontaminated farming tools, and diverted surface runoff from their potato fields, among others. Before the learning intervention, farmers of the same area had very limited knowledge of the disease characteristics, its spreading mechanisms, and its management, as the previous study on their knowledge and practices showed (Tafesse et al. 2018). The study indicated that none of the farmers knew to recognize the causes of the disease and most did not identify any other control methods apart from roguing.

This finding aligns with other studies that indicate that experiential learning improved the problem-solving capacity of farmers for integrated pest management in farmer field schools in Africa (Davis et al. 2012; Ortiz et al. 2019). Similar findings were also reported improvement of farmers' knowledge, perceptions, and practices in pest management in South America and Asia (Feder et al. 2003; Ortiz et al. 2019). Moreover, the importance of hands-on practical learning based on experiential learning principles has been reported earlier to improve the decision-making capacity of smallholder farmers in a complex farming system (Gallagher 2003; Ortiz et al. 2019).

This study also shows that farmers applied their new knowledge of the nature of the pathogen to identify possible transmission mechanisms of the disease. It demonstrates that giving due attention to the nature of the pathogen that causes bacterial wilt and diseases of other crops has an additional advantage for learning interventions to improve the capacity of smallholder farmers (Abo-Elyousr et al. 2014; Adam et al. 2015; Ortiz et al. 2019). Most other studies on farmers' knowledge and practices of crop diseases just show whether the farmers know the diseases and how they try to manage them. Little or no attention has been given to farmers' understanding of the pathogens that cause crop diseases (Abang et al. 2014; Kromann et al. 2014; Penet et al. 2016; Schreinemachers et al. 2015). Hence, this finding has considerable implications for future interventions aiming to enhance the capacity of farmers to manage crop diseases.

The study further revealed that the experiential learning aspects of the training enabled farmers to reflect on and define the feasibility of a variety of recommended bacterial wilt management methods and consider what it takes to implement the methods in their local context. The farmers rated the recommended management methods as easy to implement, difficult to implement, and very difficult to implement (Table 2). In both study sites, the farmers categorized crop rotation up to three seasons, the use of disease-free seed potato and planting on disease-free fields as very difficult to implement in their context. This reveals that the implementation of recommended methods is much 
more complex than extension workers and natural scientists assume. The identification of the feasibility of disease management methods by the farmers is in line with the theoretical notion that know-how is a context-specific type of knowledge and hence unknown to researchers and experts (Lundvall 1992; Tafesse et al. 2018). Therefore, farmers' capacity to rate the feasibility of the methods should not be considered only as an outcome of the current learning intervention. It is important to recognize that farmers' local experiential knowledge has largely contributed to their perspectives on the feasibility of the methods. Several studies also show that farmers' local experiential knowledge is more practical and relevant for sustainable agricultural development in their context (Lwoga et al. 2010; Stuiver et al. 2004; Šūmane et al. 2018).

Rating bacterial wilt management methods such as crop rotation, use of disease-free seeds, and planting potato on disease-free fields as very difficult methods to implement has huge implications for the efforts to contain the disease. These methods are important to reduce the inocula of the pathogen that causes the disease and to control it from spreading further. If the farmers do not integrate these methods with other sanitation measures, it would be difficult to contain the disease from spreading fast and wide. Hence, more efforts are needed to explore alternative options and to enhance availability of disease-free seeds.

Moreover, the evaluation of longer-term effects of similar learning interventions is recommendable. During the training, the farmers were given an opportunity to gain concrete experience with various management methods. A limitation of this study is that it was not possible to let the farmers in the two villages go through the whole experiential learning cycle of Kolb's model (concrete experience, reflective observation, conceptualization, and experimentation). They could not yet experience the results of the implemented methods. Moreover, because the learning intervention was facilitated just for one season, the farmers did not implement or test some methods like crop rotation. The farmers might test these practices in the next growing seasons depending on the feasibility of the suggested methods.

\subsection{The influence of social learning in instigating collective action for management of bacterial wilt}

Crop protection researchers promote an integrated disease management approach as an effective way to deal with bacterial wilt, which is a combination of a range of methods such as using clean seed, planting in uninfected soil, crop rotation, sanitation, and soil amendments to suppress the pathogen. Our research shows, however, that unless these measures are implemented by interdependent farmers through collective action, effective management of the disease does not happen.
Hence, for plant diseases that pose a collective risk such as potato bacterial wilt, integrated disease management needs to be complemented by a collective action approach. Therefore, the findings of this study suggest that both seed and ware potato farmers need to be involved in a well-designed learning intervention.

The findings of this study show that the social learning features of the learning intervention indeed instigated collective action among seed and ware potato farmers to manage potato bacterial wilt. It was revealed that social learning helped seed and ware potato farmers recognize their interdependency and the importance of making a collective effort to deal with the disease. Further, the study indicated that the farmers identified their roles and responsibilities for effective control of the disease. Both seed and potato farmers agreed to collectively act to manage the disease by developing a community-based bylaw. These effects are clearly the result of the learning intervention. Before the learning intervention, none of the farmers recognized the importance of collective action to deal with the disease effectively (Tafesse et al. 2018). This finding is consistent with other studies in agriculture and natural resources management that show how social learning leads to collective agreements among actors about how to jointly address complex socio-ecological problems (Albert et al. 2012; Ensor and Harvey 2015; Phuong et al. 2018; Rodela 2011). However, since developing an institutional arrangement for a collective action takes time, this study did not capture what type of rules seed and ware potato farmers will indeed develop to collectively deal with the disease.

\subsection{Implications of combining experiential and social learning to deal with complex crop diseases}

Currently, most learning interventions are designed based on either experiential learning or social learning or other learning approaches (Kolb 2015; Leeuwis and Pyburn 2002; Noguera-Mendez et al. 2016). However, a single learning approach cannot be adequate to instigate learning to deal with complex crop diseases that require collective action. Learning to deal with complex crop diseases that pose collective risk involves understanding complex socio-ecological interactions, management methods, recognizing interdependency among farmers, and making appropriate institutional arrangements to enable collective action. For instance, infectious plant diseases caused by bacterial, fungal, oomycete, and viral pathogens have diverse spreading mechanisms (Van der Plank 2013) and they are difficult to control through individual efforts, particularly in smallholder farmers' context. On the other hand, plant pathologists usually consider various abiotic and physiological disorders of plants as non-infectious (Howard et al. 1996). Non-infections plant 
diseases do not have collective risk since they do not spread from one area to the other. Hence, non-infectious diseases can be managed through individual efforts alone and may not require cooperation among farmers.

This study indicates the synergy between experiential and social learning approaches for effective management of complex crop diseases. Without social learning, smallholder farmers would not have reached consensus to collectively deal with the disease. On the other hand, without experiential learning they would not understand the dynamics of the disease, develop the skills to diagnose the disease, and evaluate the feasibility of the recommended methods and implement them to control the disease. The finding of this study matches those observed in earlier studies on complex socioecological problems that indicated the importance of social and technical innovations (Leeuwis 2004; Noguera-Mendez et al. 2016; Pahl-Wostl 2006). These findings suggest that learning interventions for the management of complex crop diseases in smallholder farmers' context could benefit from combining experiential and social learning approaches. Therefore, researchers, development practitioners, and policymakers need to consider the synergy between experiential and social learning approaches for sustainable management of infectious crop diseases. It is also essential to distinguish what can be learned better through which learning approach to design a relevant learning intervention. Moreover, it is essential to value and integrate farmers' local knowledge about the feasibility of the diverse measures in the local context into learning interventions.

The study shows that change in farmers' knowledge and social relations due to the learning intervention makes an essential contribution to effective control of the disease by improving their disease management practices. However, a learning intervention alone will not suffice for effective management of crop diseases. Several conditions impede effective bacterial wilt management in the context of Ethiopian smallholder farmers. For instance, the existing seed systems do not guarantee disease-free seed supply to the farmers (CIP 2016; Schulz et al. 2013; Woldegiorgis et al. 2013). A recent study conducted in the Ethiopian potato production system also showed that the distribution of latently infected seed potatoes has contributed to the spreading of bacterial wilt into different parts of the country (Abdurahman et al. 2017). Moreover, several previous studies reported the unavailability of quality seed potato (Gildemacher et al. 2009; Hirpa et al. 2010; Tadesse et al. 2019). Thus, if the farmers are not able to access disease-free seed potato and continue to plant infected seeds, the efficacy of the efforts being made through the implementation of farm hygiene and cultural practices cannot effectively suppress the pathogen. The absence of a quarantine system and compromise on the quality of seed potato production due to immediate needs for food security purposes (Gorfu et al. 2013; Schulz et al.
2013) could also constrain the success of farmers' aspirations to improve management of the disease. This suggests the need to further explore how other factors (economic and institutional) that may influence the efficacy of disease management efforts could be addressed.

\section{Conclusions}

The evaluation of the community-based learning intervention provides a good understanding of the importance of combining experiential and social learning approaches in designing interventions seeking to improve farmers' knowledge, perceptions, and practices to effectively respond to crop diseases like potato bacterial wilt.

The study has shown that the combination of experiential and social learning approaches enabled smallholder farmers to learn how to deal with bacterial wilt. Experiential and social learning approaches complement each other, and integrating these learning approaches can support farmers to understand how complex socio-ecological interactions aggravate the disease incidence and what effective management of the specific disease entails. Most researchers underestimate how important it is for the farmers to have a good understanding of the pathogens that cause crop diseases. But this study has found that learning about the causal agent of potato bacterial wilt and its nature has significant implications for the identification and implementation of effective disease management methods in the smallholder farmers' context. It is also indispensable to give due attention to farmers' local knowledge while facilitating a learning intervention to control this complex disease. Due to the diverse spreading mechanisms of potato bacterial wilt and the interdependency among farmers for effective control of the disease, it is important to involve both seed and ware potato farmers together in a learning intervention to foster collective action. In terms of future research, exploring tailor-made solutions that fit the smallholder context is needed, considering the biophysical and social dimensions of crop diseases.

Acknowledgements We are grateful to the Interdisciplinary Research and Education Fund (INREF) of Wageningen University and Research and the CGIAR Research Program on Roots, Tubers and Bananas (RTB) for co-funding this research. We would like to thank all interviewed farmers for their willingness to provide valuable information for the research. We also thank the anonymous reviewers and the editor for their useful comments.

Open Access This article is licensed under a Creative Commons Attribution 4.0 International License, which permits use, sharing, adaptation, distribution and reproduction in any medium or format, as long as you give appropriate credit to the original author(s) and the source, provide a link to the Creative Commons licence, and indicate if changes were made. The images or other third party material in this article are 
included in the article's Creative Commons licence, unless indicated otherwise in a credit line to the material. If material is not included in the article's Creative Commons licence and your intended use is not permitted by statutory regulation or exceeds the permitted use, you will need to obtain permission directly from the copyright holder. To view a copy of this licence, visit http://creativecommons.org/licenses/by/4.0/.

\section{References}

Abang A, Kouamé C, Abang M, Hanna R, Fotso A (2014) Assessing vegetable farmer knowledge of diseases and insect pests of vegetable and management practices under tropical conditions. Int $\mathbf{J}$ Veg Sci 20:240-253

Abdurahman A, Griffin D, Elphinstone J, Struik PC, Schulz S, SchulteGeldermann E, Sharma K (2017) Molecular characterization of Ralstonia solanacearum strains from Ethiopia and tracing potential source of bacterial wilt disease outbreak in seed potatoes. Plant Pathol 66:826-834

Abo-Elyousr KA, Seleim MA, Abd-El-Moneem KM, Saead FA (2014) Integrated effect of Glomus mosseae and selected plant oils on the control of bacterial wilt disease of tomato. Crop Prot 66:67-71

Adam RI, Sindi K, Badstue L (2015) Farmers' knowledge, perceptions and management of diseases affecting sweet potatoes in the Lake Victoria Zone region, Tanzania. Crop Prot 72:97-107

Albert C, Zimmermann T, Knieling J, von Haaren C (2012) Social learning can benefit decision-making in landscape planning: Gartow case study on climate change adaptation, Elbe valley biosphere reserve. Landsc Urban Plan 105:347-360

Allen C, Prior P, Hayward A (2005) Bacterial wilt disease and the Ralstonia solanacearum species complex. American Phytopathological Society (APS Press)

Beard CM, Wilson JP (2006) Experiential learning: a best practice handbook for educators and trainers. Kogan Page Publishers

Beers PJ, van Mierlo B, Hoes A-C (2016) Toward an integrative perspective on social learning in system innovation initiatives. Ecol Soc 21(1):33

Boud D, Keogh R, Walker D (1985) Reflection: turning experience into learning. Routledge

CIP (2016) 12th six-month program report. Better potato for better life project, Addis Ababa, Ethiopia

Colding J, Barthel S (2019) Exploring the social-ecological systems discourse 20 years later. Ecol Soc 24(1):2

Damtew E, Tafesse S, Lie R, van Mierlo B, Lemaga B, Sharma K, Struik P, Leeuwis C (2018) Diagnosis of management of bacterial wilt and late blight in potato in Ethiopia: a systems thinking perspective. NJAS-Wageningen J Life Sci 86:12-24

Davis K, Nkonya E, Kato E, Mekonnen DA, Odendo M, Miiro R, Nkuba J (2012) Impact of farmer field schools on agricultural productivity and poverty in East Africa. World Dev 40:402-413

Devaux A, Kromann P, Ortiz O (2014) Potatoes for sustainable global food security. Potato Res 57:185-199

Elphinstone J (2005) The current bacterial wilt situation: a global overview. In: Allen C, Prior P, Hayward AC (eds) Bacterial wilt: the disease and the Ralstonia solanacearum species complex. American Phytopathological Society, St. Paul, pp 9-28

Elphinstone J, Aley P (1993) Integrated control of bacterial wilt of potato in the warm tropics of Peru.[Conference paper]. ACIAR proceedings-Australian Centre for International Agricultural Research (Australia). No. 45

Elphinstone J, Allen C, Prior P, Hayward A (2005) The current bacterial wilt situation: a global overview. Bacterial wilt disease and the Ralstonia solanacearum species complex, 9-28
Ensor J, Harvey B (2015) Social learning and climate change adaptation: evidence for international development practice. Wiley Interdiscip Rev Clim Change 6:509-522

FAO (2008) Potato world: Africa-international year of the potato 2008: new light on a hidden treasure. Food and Agriculture Organization of the United Nations, Rome

Feder G, Murgai R, Quizon J (2003) Sending farmers back to school: the impact of farmer field schools in Indonesia. The World Bank

Fenwick TJ (2000) Expanding conceptions of experiential learning: a review of the five contemporary perspectives on cognition. Adult Educ Q 50:243-272

Gallagher K (2003) Fundamental elements of a farmer field school. LEISA-LEUSDEN- 19:5-6

Gebre-Selassie A, Bekele T (2012) A review of Ethiopian agriculture: roles, policy and small-scale farming systems. Bell C, Prammer J (Researchers), Eder C, Kyd-Rebenburg D, Prammer J (eds) Global growing casebook: insights into African agriculture, pp 36-65

Genin S (2010) Molecular traits controlling host range and adaptation to plants in Ralstonia solanacearum. New Phytol 187:920-928

Gildemacher PR, Demo Paul, Barker Ian, Kaguongo Wachira, Woldegiorgis Gebremedhin, Wagoire William W, Wakahiu Mercy, Leeuwis Cees, Struik Paul C (2009) A description of seed potato systems in Kenya, Uganda and Ethiopia. Am J Potato Res 86:373-382

Gorfu D, Woldegiorgis G, Kassa B, (2013) Bacterial wilt: an emerging threat to Ethiopian potato industry, pp 211-222. In: Woldegiorgis G, Berihun B, Schultz S (eds) Seed potato tuber production and dissemination: experiences, challenges and prospects. Proceedings of the national workshop on seed potato tuber production and dissemination, 12-14 March 2012, Bahir Dar, Ethiopia

Hayward A (1991) Biology and epidemiology of bacterial wilt caused by Pseudomonas solanacearum. Annu Rev Phytopathol 29:65-87

Hirpa A, Meuwissen MP, Tesfaye A, Lommen WJ, Lansink AO, Tsegaye A, Struik PC (2010) Analysis of seed potato systems in Ethiopia. Am J Potato Res 87:537-552

Howard RJ, Garland JA, Seaman WL, Grafius EJ (1996) Diseases and pests of vegetable crops in Canada. J Econ Entomol 89:1045

Keen M, Brown VA, Dyball R (2005) Social learning in environmental management: towards a sustainable future. Routledge

Kolb DA (1984) Experience as the source of learning and development. Prentice Hall, Upper Saddle River

Kolb DA (2015) Experiential learning: experience as the source of learning and development, 2nd edn. Pearson Education, Saddle River

Kromann P, Miethbauer T, Ortiz O, Forbes GA (2014) Review of potato biotic constraints and experiences with integrated pest management interventions, integrated pest management. Springer, pp 24-268

Leeuwis C (2004) Communication for rural innovation. Rethinking agricultural extension, 3rd edn. Blackwell Science, Oxford

Leeuwis C, Pyburn R (2002) Social learning for rural resource management. In: Leeuwis C, Pyburn R, Röling N (eds) Wheelbarrows full of frogs: social learning in rural resource management. Koninklijke Van Gorcum, Assen, pp 11-21

Leeuwis C, Pyburn R, Röling N (2002) Wheelbarrows full of frogs: social learning in rural resource management: international research and reflections. Koninklijke Van Gorcum, Assen

Lemaga B, Kanzikwera R, Kakuhenzire R, Hakiza J, Manzi G (2001) The effect of crop rotation on bacterial wilt incidence and potato tuber yield. Afr Crop Sci J 9:257-266

Lemaga B, Kakuhenzire R, Kassa B, Ewell P, Priou S, Allen C, Prior P, Hayward A (2005) Integrated control of potato bacterial wilt in eastern Africa: the experience of African highlands initiative. Bacterial wilt disease and the Ralstonia solanacearum species complex, pp 145-157 
Lie R, Witteveen L (2018) ICTs for learning in the field of rural communication. Handbook of communication for development and social change, pp 1-18

Lundvall B-A (1992) National innovation system: towards a theory of innovation and interactive learning. Pinter, London

Lwoga ET, Ngulube P, Stilwell C (2010) Managing indigenous knowledge for sustainable agricultural development in developing countries: knowledge management approaches in the social context. Int Inf Libr Rev 42(3):174-185

Michelson E (1999) Carnival, paranoia and experiential learning. Stud Educ Adults 31:140-154

Noguera-Mendez P, Molera L, Semitiel-Garcia M (2016) The role of social learning in fostering farmers' pro-environmental values and intentions. J Rural Stud 46:81-92

Ortiz O, Garrett K, Health J, Orrego R, Nelson R (2004) Management of potato late blight in the Peruvian highlands: evaluating the benefits of farmer field schools and farmer participatory research. Plant Dis 88:565-571

Ortiz O, Nelson R, Olanya M, Thiele G, Orrego R, Pradel W, Kakuhenzire R, Woldegiorgis G, Gabriel J, Vallejo J (2019) Human and technical dimensions of potato integrated pest management using farmer field schools: International Potato Center and partners' experience with potato late blight management. J Integr Pest Manag 10:4

Pahl-Wostl C (2006) The importance of social learning in restoring the multifunctionality of rivers and floodplains. Ecol Soc 11(1): 10

Pahl-Wostl C, Craps M, Dewulf A, Mostert E, Tabara D, Taillieu T (2007) Social learning and water resources management. Ecol Soc 12(2):5

Pahl-Wostl C, Tàbara D, Bouwen R, Craps M, Dewulf A, Mostert E, Ridder D, Taillieu T (2008) The importance of social learning and culture for sustainable water management. Ecol Econ 64:484-495

Palis FG (2006) The role of culture in farmer learning and technology adoption: a case study of farmer field schools among rice farmers in central Luzon, Philippines. Agric Hum Values 23:491-500

Paolisso M, Prell C, Johnson KJ, Needelman B, Khan IM, Hubacek K (2019) Enhancing socio-ecological resilience in coastal regions through collaborative science, knowledge exchange and social networks: a case study of the Deal Island Peninsula, USA. Soc-Ecol Pract Res 1(2):109-123

Penet L, Barthe E, Alleyne A, Blazy J (2016) Disease risk perception and diversity of management strategies by farmers: the case of anthracnose caused by Colletotrichum gloeosporioides on water yams (Dioscorea alata) in Guadeloupe. Crop Prot 88:7-17

Percy R (2005) The contribution of transformative learning theory to the practice of participatory research and extension: theoretical reflections. Agric Hum Values 22:127-136

Phuong LTH, Wals A, Sen LTH, Hoa NQ, Van Lu P, Biesbroek R (2018) Using a social learning configuration to increase Vietnamese smallholder farmers' adaptive capacity to respond to climate change. Local Environ 23:879-897

Pincus L, Ballard H, Harris E, Scow K (2018) Seeing below the surface: making soil processes visible to Ugandan smallholder farmers through a constructivist and experiential extension approach. Agric Hum Values 35:425-440

Reed M, Evely AC, Cundill G, Fazey IRA, Glass J, Laing A, Newig J, Parrish B, Prell C, Raymond C (2010) What is social learning? Ecol Soc 15(4):r1

Roberts TG (2006) A philosophical examination of experiential learning theory for agricultural educataors. J Agric Educ 47:17

Rodela R (2011) Social learning and natural resource management: the emergence of three research perspectives. Ecol Soc 16(4):30
Rodela R (2013) The social learning discourse: trends, themes and interdisciplinary influences in current research. Environ Sci Policy 25:157-166

Röling N, Wagemakers MAE (1998) Facilitating sustainable agriculture: participatory learning and adaptive management in times of environmental uncertainty. Cambridge University Press, Cambridge

Roopa K, Gadag AS (2019) Management of soil-borne diseases of plants through some cultural practices and actinobacteria, plant health under biotic stress. Springer, pp 129-145

Savary S, Willocquet L, Pethybridge SJ, Esker P, McRoberts N, Nelson A (2019) The global burden of pathogens and pests on major food crops. Nat Ecol Evol 3:430

Schreinemachers P, Balasubramaniam S, Boopathi NM, Ha CV, Kenyon L, Praneetvatakul S, Sirijinda A, Le NT, Srinivasan R, Wu M-H (2015) Farmers' perceptions and management of plant viruses in vegetables and legumes in tropical and subtropical Asia. Crop Prot 75:115-123

Schulz S, Woldegiorgis G, Hailemariam G, Aliyi A, Haar J, Shiferaw W (2013) Sustainable seed potato production in Ethiopia: from farm-saved to quality declared seed, pp 61-71. In: Woldegiorgis G, Berihun B, Schultz S (eds) Seed potato tuber production and dissemination: experiences, challenges and prospects. Proceedings of the national workshop on seed potato tuber production and dissemination, 12-14 March 2012, Bahir Dar, Ethiopia

Seaman J (2008) Experience, reflect, critique: the end of the "learning cycles" era. J Exp Educ 31:3-18

Spielman DJ, Davis K, Negash M, Ayele G (2011) Rural innovation systems and networks: findings from a study of Ethiopian smallholders. Agric Hum Values 28(2):195-212

Stevenson WR, Loria R, Franc GD, Weingartner DP (2001) Compendium of potato diseases. American Phytopathological Society

Strange RN, Scott PR (2005) Plant disease: a threat to global food security. Annu Rev Phytopathol 43:83-116

Stuiver M, Leeuwis C, van der Ploeg JD (2004) The power of experience: farmers' knowledge and sustainable innovations in agriculture. In: Wiskerke JSC, van der Ploeg JD (eds) Seeds of transition: essays on novelty production, niches and regimes in agriculture. Van Gorcum, Assen

Šūmane S, Kunda I, Knickel K, Strauss A, Tisenkopfs T, de los Rios I, Rivera M, Chebach T, Ashkenazy A (2018) Local and farmers' knowledge matters! How integrating informal and formal knowledge enhances sustainable and resilient agriculture. J Rural Stud 59:232-241

Suzanne Nederlof E, Odonkor EN (2006) Lessons from an experiential learning process: the case of cowpea farmer field schools in Ghana. J Agric Educ Ext 12:249-271

Tadele Z (2017) Raising crop productivity in Africa through intensification. Agronomy 7:22

Tadesse Y, Almekinders CJ, Griffin D, Struik PC (2019) Collective production and marketing of quality potato seed: experiences from two cooperatives in Chencha. Ethiopia. Forum Dev Stud 47(1):139-156

Tafesse S, Damtew E, van Mierlo B, Lie R, Lemaga B, Sharma K, Leeuwis C, Struik PC (2018) Farmers' knowledge and practices of potato disease management in Ethiopia. NJAS-Wageningen $\mathrm{J}$ Life Sci 86:25-38

Van de Fliert E (1993) Integrated pest management: farmer field schools generate sustainable practices: a case study in Central Java evaluating IPM training. Wageningen Agricultural University, Wageningen

Van der Plank JE (2013) Plant diseases: epidemics and control. Elsevier van Mierlo B, Beers PJ (2018) Understanding and governing learning in sustainability transitions: a review. Environ Innov Societal Transit 34:255-269 
van Mierlo B, Leeuwis C, Smits R, Woolthuis RK (2010) Learning towards system innovation: evaluating a systemic instrument. Technol Forecast Soc Change 77:318-334

Woldegiorgis G, Negash K, Solomon A, Chindi A, Lemaga B (2013) Participatory potato seed production: experiences from west and southwest Shewa, and Gurage zones, pp. 152-172. In: Woldegiorgis G, Berihun B, Schultz S (eds) Seed potato tuber production and dissemination: experiences, challenges and prospects. Proceedings of the national workshop on seed potato tuber production and dissemination, 12-14 March 2012, Bahir Dar, Ethiopia

Yuliar, Nion YA, Toyota K (2015) Recent trends in control methods for bacterial wilt diseases caused by Ralstonia solanacearum. Microbes Environ 30:1-11

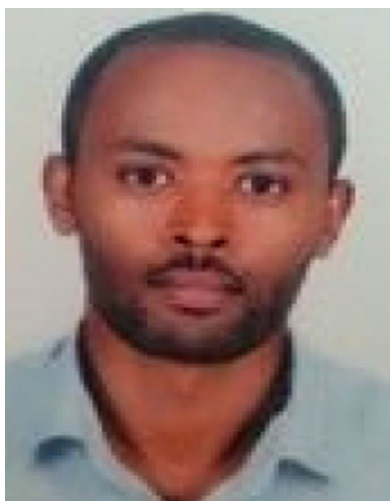

Shiferaw Tafesse is a $\mathrm{PhD}$ student at Wageningen University and Research. His research focuses on exploring the social and biophysical dimensions of bacterial wilt and developing an effective management strategy for smallholder potato farmers.
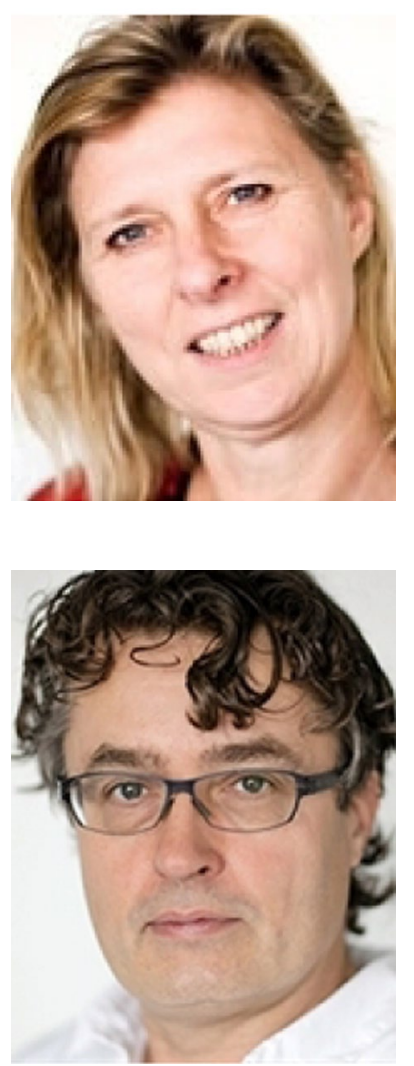

Cees Leeuwis is a professor of Knowledge, Technology and Innovation. He studies processes of socio-technical innovation and transformation in networks, collaboration between different disciplines, research for development policy, the functioning of innovation support systems, and the role of innovation platforms, communication, extension, and brokers.

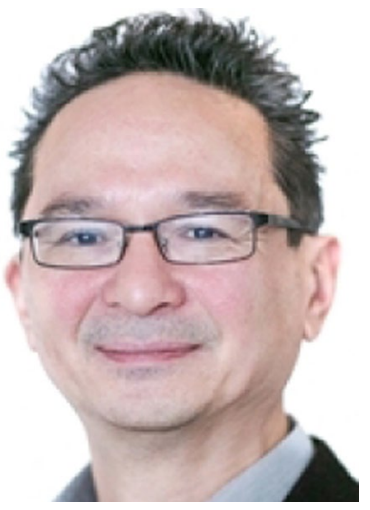

Rico Lie is a social anthropologist working at the research group Knowledge, Technology and Innovation, Wageningen University and Research. He previously worked at the University of Brussels in Belgium and the Universities of Nijmegen and Leiden in The Netherlands. At Wageningen University, he is an assistant professor in international communication.

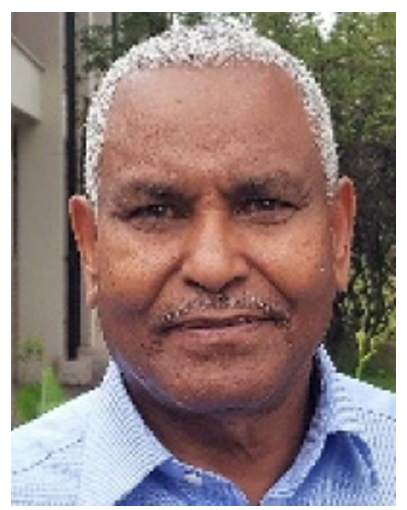

Berga Lemaga is a Senior Agronomist and a CIP-Ethiopia Country Manager. He also served as a Research and Extension Director at the Ethiopian Agricultural Transformation Agency, led a regional potato and sweet potato improvement network of ten countries in sub-Saharan Africa and managed regional potato projects.

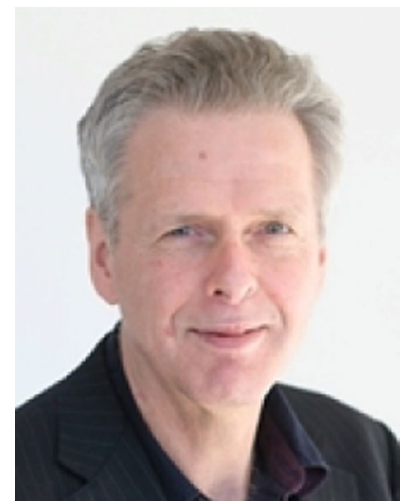

Paul C. Struik is a professor of agronomy and crop physiology working at Wageningen University and Research. In his research, he focuses on modeling of photosynthesis in $\mathrm{C} 3$ and $\mathrm{C} 4$ crops, genotype $\mathrm{x}$ environment interactions in monocots and dicots, and the agronomy and physiology of potato. 